\title{
ENTOMOLOGY IN THE UNITED STATES NATIONAL MUSEUM
}

The day has long passed when American scientific activities can be restricted to a narrow field. Whether we regard the economic needs or the intellectual development, we find ourselves compelled to consider the whole range of science, limited only by our resources and the powers of the human mind. In the field of Entomology this involves, among other things, access to adequate collections of insects, including not only those found in North America, but the species of the whole world. The leading European countries have long appreciated such needs, and have built up collections to which Americans have to make pilgrimages when engaged in comprehensive studies of insect groups. There is no reason why we should not possess facilities for work at least equal to those of any other country. We have the greatest material resources of any nation at the present time, and certainly are not lacking in the ability to carry on the work.

The species of insects are far more numerous than those of any other group of animals; in fact the described forms exceed those of all other groups combined. Very many of them are of supreme importance and interest to man, as destroyers of our crops, carriers of the germs of disease, enemies of other injurious insects, or sources of some of our most important economic products. All know the value of the silkworm and the honey bee, but few realize the services of the best of parasitic insects, which keep down the enemies of our crops, and without which agriculture would be impossible. All are aware that numerous insects are injurious to plants, but comparatively few know that many of the most harmful of these have been introduced from abroad. The greatest danger to our crops, or even to our health, may arise from insects accidentally brought from foreign countries through the operations of commerce. The San Jose scale, dangerous enemy of many fruits, came from Asia; the cottony cushion scale, which once threatened the extinction of the orange industry in California, came from Australia. The gypsy moth, which has cost this country hundreds of thousands of dollars to fight, is European. The cotton boll weevil, even more to be dreaded, invaded the United States from Mexico and Central America. For urgent practical reasons, therefore, as well as in order to complete and organize our knowledge, we need to know the insects of all countries, and to have them represented in at least one American collection.

This obvious requirement of a great collection representing the insects of all lands, cannot be met without Congressional aid. The National Museum, under present conditions, or better, limitations, cannot possibly adopt an adequate policy of entomological development. The two prime obstacles are lack of sufficient curators and lack of space. The present force of curators, even with the aid afforded by the members of the Bureau of Entomology, cannot arrange and classify the collections already on hand, incomplete as these are. Some of the men work overtime and on holidays, while help is sometimes obtained from those not officially connected with the Museum. But all these 
activities lamentably fail to meet the whole need. The Museum should have enough expert curators to keep classified and in order, the available material in every group of insects, and to furnish identifications and other aid to economic entomologists and other workers in every State. Should a sufficient curatorial force be supplied, however, it would be helpless in the present crowded condition of the department. There is hardly room to move around, and almost no space for new cabinets. The only way out seems to be through the erection of a new building of suitable size; fireproof, but not necessarily of any great architectural pretensions.

Granting the building and the curators, with suitable rules and arrangements to ensure the proper care of all the collections, what more should be demanded? Undoubtedly collectors and students would present or bequeath their materials on a scale previously unheard of, because of the great services they had received from the Museum and their confidence in it as a repository of types and other priceless specimens. This, however, would not suffice. Funds should be available for explorations within the United States and abroad, to discover insects hitherto unknown or unrepresented in the Museum.

With curators, building, and adequate collections, we are still confronted by another urgent need. The results of the work done must be made available to scientific men in every part of the country. This can only be brought about through the creation of adequate publishing facilities, insuring the reasonably prompt appearance of each work completed. At the present time authors hesitate to undertake large monographs not knowing when they will see the light of publicity, nor indeed whether they will ever do so.

Prepared by the Committees to investigate conditions and needs of the United States National Museum.

Entomological Society of America:

T. D. A. Cockerell,

Professor of Zoology, University of Colorado.

Herbert OsBorn,

Research Professor, Department of Zoology, Ohio State University.

WM. BARNES,

Surgeon, Decatur, Illinois.

WM. M. WHEELER,

Dean Bussey Institute, Harvard University.

J. G. NeEDham,

Head, Department of Entomology, Cornell University.

\section{American Association Economic} Entomologists:

JoHn J. Davis,

In charge, Japanese Beetle Project,

New Jersey State Department of Agriculture.

VERNON L. KelloGG,

Secretary, National Research Council.

E. P. FeLt,

State Entomologist, New York.

HERBERT OSBORN,

Research Professor, Department of Zoology and Entomology, Ohio State University.

E. D. BALL,

State Entomologist, Iowa.

Committee.

(Approved and adopted at St. Louis, Missouri, by the Entomological Society of America, on December 30, 1919, and by the American Association of Economic Entomologists, on January 2, 1920.) 


\section{$2 \mathrm{BHL}$ Biodiversity Heritage Library}

1920. "Entomology in the United States National Museum." Annals of the Entomological Society of America 13, 131-132.

https://doi.org/10.1093/aesa/13.1.131.

View This Item Online: https://www.biodiversitylibrary.org/item/43848

DOI: https://doi.org/10.1093/aesa/13.1.131

Permalink: https://www.biodiversitylibrary.org/partpdf/193521

\section{Holding Institution}

Smithsonian Libraries

\section{Sponsored by}

Smithsonian

\section{Copyright \& Reuse}

Copyright Status: NOT_IN_COPYRIGHT

This document was created from content at the Biodiversity Heritage Library, the world's largest open access digital library for biodiversity literature and archives. Visit BHL at https://www.biodiversitylibrary.org. 